\title{
Parents' Perceptions of Distance Learning during Covid-19 Pandemic in Rural Indonesia
}

\author{
Delipiter Lase, Sonny Eli Zaluchu, Dorkas Orineti Daeli, Amurisi Ndraha \\ piterlase@sttsundermann.ac.id
}

This study was developed to investigate parents' perceptions and attitudes towards distance learning in response to many schools' closure due to the Covid-19 pandemic. This research uses a qualitative approach. The research subjects consisted of parents of elementary school students in Gunungsitoli City who were determined by purposive sampling technique, totaling twenty-four people. The data were collected using semistructured interview techniques and analyzed using thematic analysis techniques. This study shows that distance learning or learning from home in a research context takes the form of online and offline learning. For parents, the learning approach implemented during the Covid-19 pandemic emergency must be lived and supported in the absence of other options. Although parents do not have negative perceptions, distance learning has increased the burden on parents or families economically, psychologically, and socially. The lack of parental involvement and support in children's learning process at home is generally due to the lack of time and the inability of parents to become teachers for their children at home. Actions to accompany and support the learning process of children at home are carried out to provide internet packages, help children master the material, and participate in completing assignments or tests given by the teacher. The surprising finding from this study is the decline in learning motivation and cognitive abilities of children. Parents hope that distance learning is not extended in the remainder of the 2020/2021 school year so that children can study again at educational institutions.

Keywords:

\section{Introduction}

The Covid-19 pandemic has caused changes in patterns of interaction and activity in almost all aspects of human life, including the education sector. Concerning education, the Covid-19 pandemic has disrupted students' lives in various ways, which is a particular challenge for students. They will not complete their school curriculum and assessments in the usual way, and they have also been separated from their social group. Agree or disagree, schools must adjust learning management, switch from conventional classes to distance learning both online and offline, although, in certain areas in Indonesia, schools still apply conventional (face-to-face) learning, especially in areas where the Covid-19 pandemic has not yet appeared.

Data as of August 20, UNESCO (2020) recorded 673,114,704 students affected, 38.4\% of the total students registered, and 30 countries closed all schools in their countries. Most governments around the world have temporarily closed educational institutions to contain the spread of the Covid-19 pandemic. This national closure affects more than $60 \%$ of the world's student population. Several other countries have implemented local closures affecting millions of additional students.

In Indonesia, the Ministry of Education and Culture stated that as many as 68 million students ranging from early childhood education to high school levels Indonesia were 
also affected by the Covid-19 pandemic (Puspita, 2020). They were forced to learn from home due to the Covid-19 pandemic. Of this number, "only about 34.5 percent can access online education services," said Abdul Fikri Faqih (Deputy Chairman of Commission X DPR) in Viva (2020).

Responding to the closure of most schools in Indonesia, the Indonesian Government, through the Ministry of Education and Culture, issued Circular No. 4 of 2020 dated 24 March 2020 concerning the National Education Policy during the Covid-19 emergency period. In this circular, it is explained that the teaching and learning process is carried out at home through distance learning (Pembelajaran Jarak Jauh = PJJ). In the aftermath of this national policy, 646,200 schools were closed starting from early childhood to tertiary education levels. As a result, 68.8 million students study at home, and 4.2 million teachers and lecturers teach from home (Faqir, 2020). Concerning this policy, a survey conducted by the Ministry of Education and Culture in April 2020 showed 97.6 percent of schools had carried out learning activities from home, leaving 2.4 percent of other schools to continue carrying out teaching and learning activities in educational institutions.

Following up on Circular No. 4/2020, the Ministry of Education issued Circular No. 15/2020 on Guidelines for The Implementation of Study from Home (Belajar dari Rumah = BDR) in the Emergency Period of the Spread of Covid-19. This circular is intended to (1) ensure the fulfillment of the right of learners to obtain educational services during the Covid-19 emergency; (2) protect the citizens of the education unit from the adverse effects of Covid-19; (3) prevent the spread and transmission of Covid-19 in education institutions; and (4) ensure the fulfillment of psychosocial support for educators, learners and parents or guardians.

The study from home is another term for distance learning models developed in Indonesia and implemented through two approaches, namely (1) PJJ online and (2) PJJ offline (Kemendikbud, 2020). Especially for offline learning, it is interpreted more broadly than just traditional shopping in the pre-internet era, where the teaching and learning process must be done at the same time and place (Pei \& Wu, 2019). Students learn through physical learning resources such as student books, teacher guidelines, modules, and student worksheets (Lembar Kerja Peserta Didik= LKPD) in this offline learning. In this model, students can also access the content of lessons through TVRI and Radio broadcasts.

The implementation of distance learning to ensure education continues and inhibit the spread of the Covid-19 pandemic does not mean that it does not face challenges and obstacles. In addition to positive benefits such as accelerating technology integration, information, and communication in learning activities, some obstacles are also faced. Among others, teachers and students are not used to using a fully formulated and fully online learning system; therefore, additional support and mentoring are needed to adapt to the new learning model.

Previous research findings indicate that students generally prefer face-to-face learning in class rather than home learning with online learning because it is easier to understand the material when the teacher explains it directly (face to face). In the classroom, they can interact and learn together (Megawanti et al., 2020). Studying at home is constrained due to limited internet quota (Arifin, 2020). Only 56\% expressed satisfaction with the application of e-learning (Krishnapatria, 2020). 78.6\% of respondents felt that conventional classes are more effective than online learning 
(Adnan \& Anwar, 2020). Although disliked, but in previous research results, research respondents agreed that online learning is the right solution in this time of crisis.

Besides, teachers experienced increased spending on quota purchases, tired of staying at home, and going back to school to interact with students immediately. It takes much time, even working late into the night to prepare learning materials and give feedback; unable to monitor students' learning progress (Putri et al., 2020). Teachers work late into nights and weekends to develop learning materials and support their online students (Jandrić, 2020).

How about the parents? Parents have limited abilities in providing online learning facilities for children (Herliandry et al., 2020). "The decline in economic productivity because parents have to take care of children while working" (Zaharah \& Kirilova, 2020). When households are locked up in their homes by Covid-19, parents and carers may be very anxious about their economic future, so learning at home is not easy, especially for low-motivation children (Skulmowski \& Rey, 2020). Online learning requires an internet connection, which has, therefore, increased parental expenses (Dewi, 2020).

Based on the explanation above, this study is intended to investigate how education institutions, mainly elementary school education levels, apply distance learning (studying from home) during the Covid-19 pandemic. Besides, this study also aims to obtain an overview of parents' perceptions and attitudes towards distance learning and their actions in supporting their children's studies.

This problem becomes the object of research for several reasons. The research generally focuses on investigating teachers' readiness in conducting distance learning and aimed at obtaining an overview of teacher perception, students, and the effectiveness of distance learning. On the other hand, until this work began in early August 2020, research on how parents' perceptions are tapped into distance learning implementation, especially in rural Indonesia, has not been touched by many researchers.

\section{Method}

This research took place in the City of Gunungsitoli. The City of Gunungsitoli is one of 514 Regencies/Cities in Indonesia. Geographically, it is located in an archipelago, namely Nias Island, and is part of 34 regencies/cities in North Sumatra. Although the city is administratively categorized as 'city' due to its geographic location in an archipelago - this area is an area where around $65.5 \%$ of students cannot access online education services.

This city has 186 education institutions consisting of 115 elementary schools or equivalent, 40 junior high schools or equivalent, 17 high school equivalent, and 14 vocational high schools or equivalent. This study took the subject of Elementary School, where at this level of education, the City of Gunungsitoli has a total of 18,213 students spread across elementary schools or equivalent.

Until August 2020, based on the spread rate of the Covid-19 pandemic, the City of Gunungsitoli is in the Green zone. The zone in which the school can be allowed to conduct face-to-face learning with certain restrictions.

This research uses descriptive qualitative research. According to Moleong (2012, p. 6), qualitative research intends to understand the phenomenon of what is experienced 
by the research subject. Considerations for choosing qualitative approaches include research to dive into the depths of complexity and processes; the associated variables have not been identified (Marshall \& Rossman, 2015, p. 46). Data sources and informants (participants) consisted of students' parents in grades 4-6 of elementary schools in the City of Gunungsitoli area. In addition to geographical area considerations, participants (Table 1) numbered 24 (twenty-four) people determined using purposive sampling techniques based on competence and not based on representation (Bernard \& H. Russell, 2006).

Table 1. Characteristics of Participants

\begin{tabular}{|c|c|c|c|c|c|}
\hline Name & Age & Gender & Education & Job & Address \\
\hline $\mathrm{R}_{1}$ & 42 & Male & Bachelor & Gov. employees & Gunungsitoli Idanoi \\
\hline $\mathrm{R}_{2}$ & 40 & Male & Junior High School & Farmer/Fisherman & Gunungsitoli Idanoi \\
\hline $\mathrm{R}_{3}$ & 38 & Female & High School & Entrepreneur & Gunungsitoli Idanoi \\
\hline $\mathrm{R}_{4}$ & 39 & Male & Elementary School & Daily Labor & Gunungsitoli Idanoi \\
\hline $\mathrm{R}_{5}$ & 40 & Female & High School & Private employees & Gunungsitoli Idanoi \\
\hline $\mathrm{R}_{6}$ & 43 & Male & Bachelor & Gov. employees & Gunungsitoli Alo'oa \\
\hline $\mathrm{R}_{7}$ & 40 & Female & Elementary School & Farmer & Gunungsitoli Alo'oa \\
\hline $\mathrm{R}_{8}$ & 40 & Male & Bachelor & Gov. employees & Gunungsitoli \\
\hline $\mathrm{R}_{9}$ & 47 & Female & Bachelor & Gov. employees & Gunungsitoli \\
\hline $\mathrm{R}_{10}$ & 38 & Male & Junior High School & Farmer/Fisherman & Gunungsitoli \\
\hline $\mathrm{R}_{11}$ & 38 & Male & Elementary School & Farmer/Fisherman & Gunungsitoli \\
\hline $\mathrm{R}_{12}$ & 40 & Male & Elementary School & Daily Labor & Gunungsitoli \\
\hline $\mathrm{R}_{13}$ & 39 & Male & Junior High School & Daily Labor & Gunungsitoli \\
\hline $\mathrm{R}_{14}$ & 43 & Female & Bachelor & Entrepreneur & Gunungsitoli \\
\hline $\mathrm{R}_{15}$ & 39 & Female & Baccalaureate & Private employees & Gunungsitoli \\
\hline $\mathrm{R}_{16}$ & 41 & Male & Bachelor & Gov. employees & Gunungsitoli Selatan \\
\hline $\mathrm{R}_{17}$ & 39 & Male & Junior High School & Farmer/Fisherman & Gunungsitoli Selatan \\
\hline $\mathrm{R}_{18}$ & 42 & Female & Baccalaureate & Entrepreneur & Gunungsitoli Selatan \\
\hline $\mathrm{R}_{19}$ & 41 & Male & Bachelor & Gov. employees & Gunungsitoli Barat \\
\hline $\mathrm{R}_{20}$ & 40 & Male & Junior High School & Farmer & Gunungsitoli Barat \\
\hline $\mathrm{R}_{21}$ & 38 & Female & Bachelor & Gov. employees & Gunungsitoli Utara \\
\hline $\mathrm{R}_{22}$ & 40 & Male & Junior High School & Farmer/Fisherman & Gunungsitoli Utara \\
\hline $\mathrm{R}_{23}$ & 39 & Female & High School & Entrepreneur & Gunungsitoli Utara \\
\hline $\mathrm{R}_{24}$ & 40 & Male & Junior High School & Daily Labor & Gunungsitoli Utara \\
\hline
\end{tabular}

Data is collected using semi-structured interview techniques. Interviews are conducted face-to-face and telephone conversations (Bernard \& H. Russell, 2006). Face-to-face interviews and telephone conversations lasted for three weeks, from 3 - 22 August 2020, with a duration of 10-15 minutes per participant. Data analysts, using thematic analysis, are one way to analyze the data to identify patterns or find themes through the data collected (Heriyanto, 2018).

\section{Results}

\section{Theme 1: Implementation of distance learning in the City of Gunungsitoli}

Of the 24 parents interviewed, nine respondents (37.5\%) stated that their children study from home in online learning. Parents prefer this approach because they are worried that children are exposed to Covid-19. 
"We are worried that children will become victims of the spread of the Covid19 pandemic. Even though offline learning is implemented, we prefer the online approach. All lesson content or LKPD, including assignments and daily tests, are sent to children via social media (WhatsApp). Then, materials and assignments completed by the children are returned to the homeroom teacher or subject teacher, whether in the form of documents, videos, and podcasts. The material that is not understood by the children is usually discussed through the class WA group or directly to the subject teacher" (R8 and R9).

In contrast to the nine respondents above, $15(62.5 \%)$ of the total respondents said children learn from home in offline learning. The consideration of this election, among others, is related to the problem of the unstable network and the absence of devices or equipment to support children's learning activities at home.

"Due to various limitations, including unstable networks, lack of technical learning equipment for children - such as laptops, tablets or cellphones, printers and others, including the absence of internet package fees and the ability to operate the required software, "he said. In the end, we prefer children to study at home in the form of offline learning. At the beginning of every week, parents pick up the LKPD and take them back to school according to the homeroom teacher's schedule or the subject teacher" (R7, R13, and R22).

Government officials confirmed the research findings above in the Basic Education section of the Gunungsitoli City Education Office. Said that distance learning (PJJ) at the elementary school education level is carried out using online and offline approaches. The City of Gunungsitoli Education Office has not been able to implement full online distance learning due to the schools' geographical location mostly in sub-districts and villages. In this area, it is not easy to find adequate telecommunication infrastructure with a stable network.

\section{Theme 2: Parents' perceptions of distance learning}

Parents' perceptions of distance learning at this time of crisis were mixed. Difficult to find a strong statement between agreeing or disagree; like and dislike. Parents generally do not have negative views or resistance to distance learning, but for parents, this is unexpected, new, burdensome, and forces them to adjust quickly.

"... this is complicated, children and including us, parents have no experience with the current management of distance learning. Yes, the children also have no other choice - like it or not, the children have to do this new learning model. Even though the school is closed, the learning process cannot be stopped continuously in an unpredictable time" (R3, R10, and R20).

The spread of the Covid-19 pandemic is an unprecedented situation. It has made the majority of parents worry about the pandemic's negative impact on children's education. It is concerning; there are still parents (22\%) who do not care about the impact of Covid-19 on their children's education. 


\section{Theme 3: Parental involvement in children's learning at home}

The mother as the primary caregiver (in most cases) shows her role in supporting children's education and learning. The interview results showed that 13 (thirteen) parents $(54.17 \%)$ gave time even though they were limited to be involved with children's learning at home. As many as 7 or $29.17 \%$ of parents conclusively claimed to have much free time to accompany children's learning activities at home. The rest are very busy parents, so they rarely monitor children's learning activities at home and hand over assistance for children's learning activities to other family members (Figure $1)$.

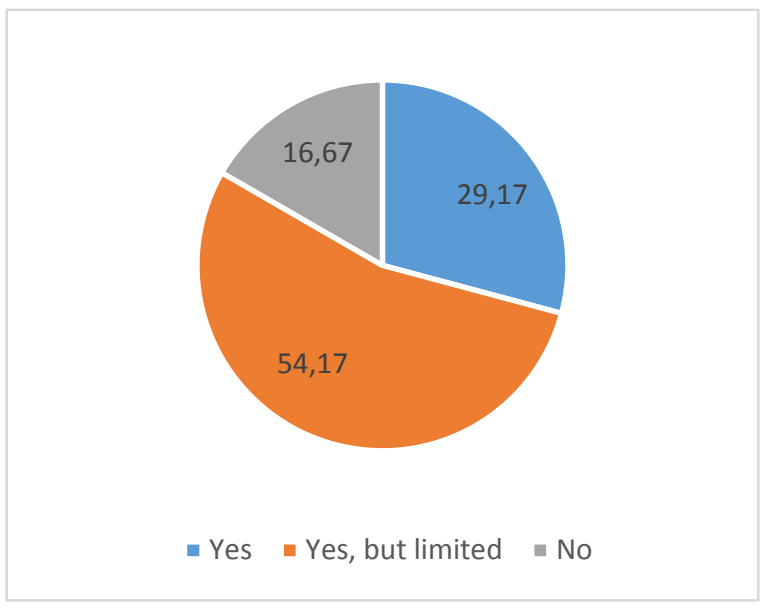

Figure 1. Availability of time for parents to accompany children's learning activities at home
"The best time for us to accompany the children to study is at night because we have to work from morning to evening, and this is a relatively short time because children are used to sleeping early at night" (R5 and R15).

"Incidentally, my wife and I work as government employees so that other family members mostly accompany children's learning activities at home. Except at night, we check the study materials and assignments that must be completed by the children" (R8, and R16).

"I am more involved in the children's learning at home in the morning. So that, in the afternoon or evening, the children rest or play more" (R14).

When asked if they can or capable of supporting children at home in terms of learning. $37.5 \%$ feel they can and have the ability to support their child's studies at home. Another $62.5 \%$ appear to be hesitant and try with limited abilities (Figure 2).

"My child goes to the Christian elementary school BNKP Gunungsitoli and is in grade 5. Every week the children receive 5-7 learner worksheet (LKPD). So far, there have been no obstacles, materials, and questions that the children cannot understand; we explain it well; sometimes, it has to be repeated to understand better. However, of course, the methods we use are not as good as teachers' teaching methods in schools" (R15 and R16).

"If it is said to be capable, indeed, it is not. Because if it is capable of doing what the parenting stress, then love to get angry. The children at the house do not want to learn 
when not reminded and monitored. The trouble is, the kids are more respectful (of fear) to their teacher than the parent at home. Quite less comprehensive, what is the parent's weakness in general - there is a view among the parent that educational affairs are school affairs" (R11 and R19).

The results of interviews with other parents showed that distance learning could incite violence against children at home. Parents are claiming that "Children at home do not want to learn if not told, already so - the materials and tasks given from the school are also difficult for the child to understand; thus, parents are angry and tend to behave violently until hit" (R17).

Theme 4: Parental actions and support for children's learning activities at home

Switching from actual perception to parental action, it was informed that $70.83 \%$ of them always check or monitor the student worksheet (LKPD) from the school. Over $65 \%$ of parents support children's learning activities at home in the form of providing internet packages; help explain and complete the learner worksheet (LKPD). 16.67\% support children's education and learning to provide equipment (such as mobile phones, tablets, laptops) and less than $10 \%$ in the form of private study and or courses (Figure 3).

"...... not much is done, besides providing internet packages, we help children

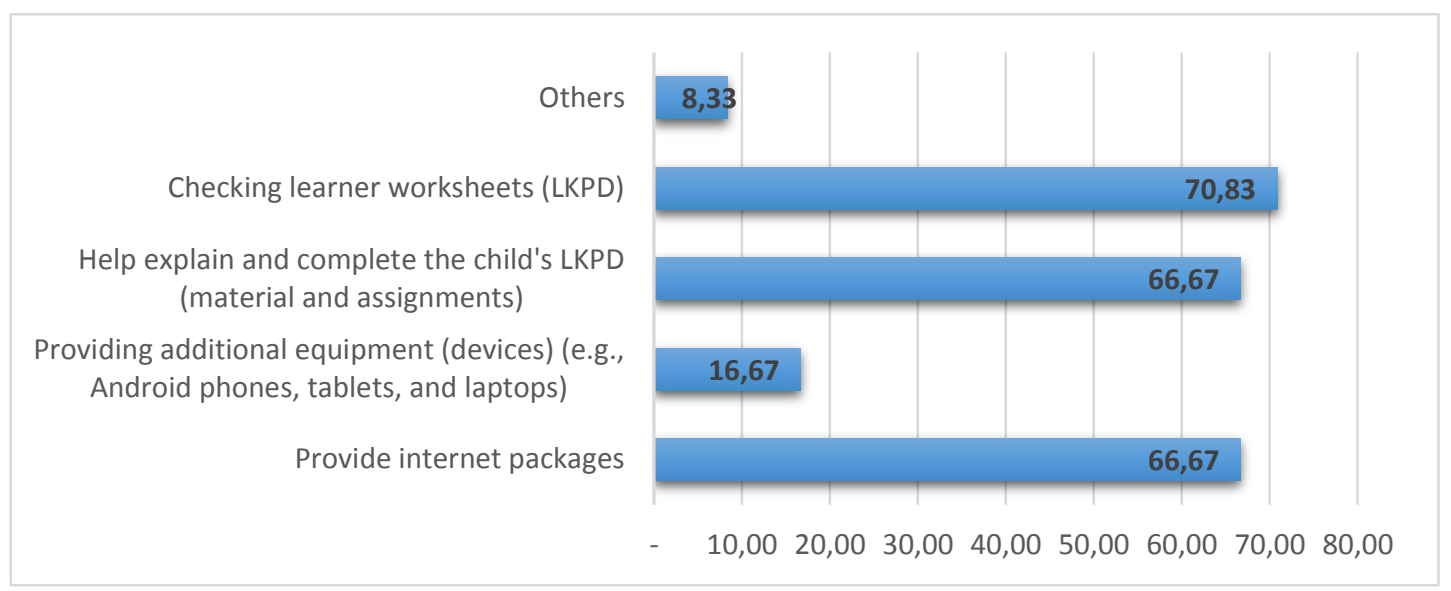

Figure 3. Parental actions and support for children's learning activities at home explain poorly understood material and participate in completing assignments or exam questions given from school. Above all -we monitor their interactions with people other than their families to keep them likely to contract Covid-19" (R5).

The Covid-19 pandemic has forced the closure of almost all schools in Indonesia. To ensure the education process continues, the Ministry of Education pursued a policy to reopen the education institutions in the new school year of July 2020. This policy only applies to regions where the spread of Covid-19 is relatively low (green and yellow zones). While in the red and orange zone, the school remains closed. The following image shows the obstacles and challenges parents face over the implementation of distance learning. 
Theme 4: Barriers and challenges faced by parents towards the implementation of distance learning

Organizing education with distance learning approaches online and offline does not mean there are no barriers or challenges. Over $54.4 \%$ of parents complained of increased children's education costs, $41.9 \%$ felt depressed, stressed, and frustrated by the increasing burden of their thoughts and work. 58.7\% of parents have difficulty managing the time between accompanying their children to study with daily work. The concern is that $48.45 \%$ of parents admitted that their child's learning motivation decreases, and $29.4 \%$ of parents feel that their cognitive abilities are also decreasing (Figure 4).

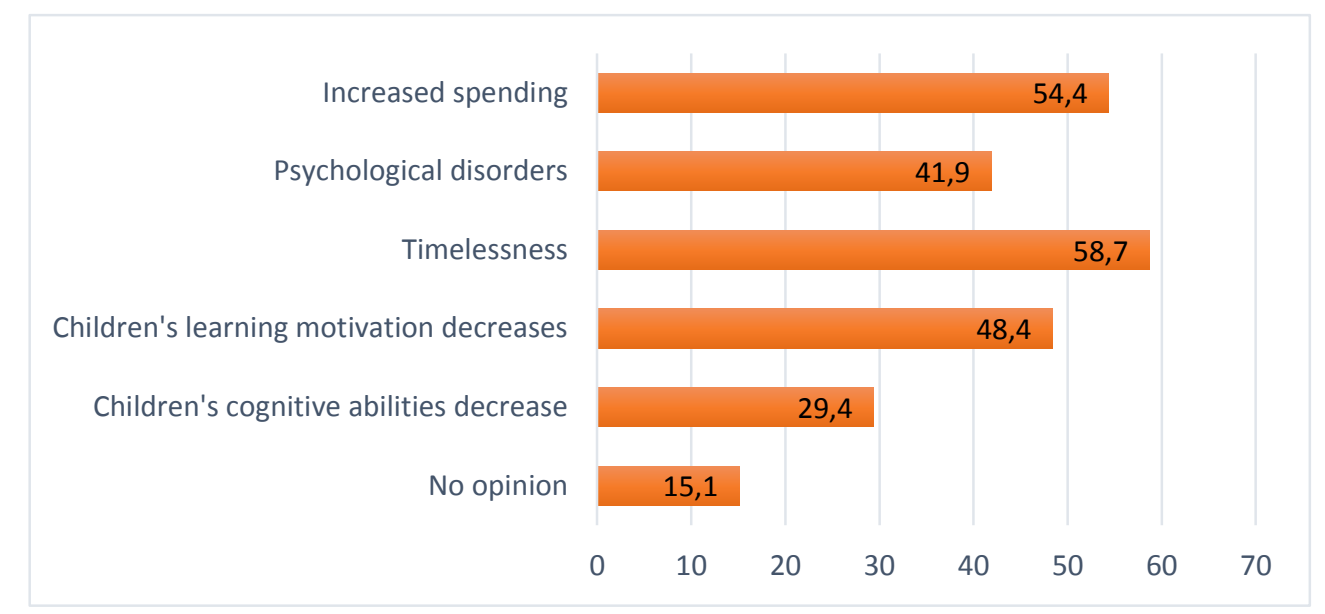

Figure 4. Barriers and challenges parents face with distance learning

"The cost of children's education increases, the expenditure becomes greater. We had to buy internet packages so that children could access online learning resources. We are also forced to buy new mobile phones so that children can follow online learning" (R4 and R9).

" ...... not only that, in this remote defense - children's learning motivation decreases, if not supervised they instead spend time and packages to play games. It is not uncommon for us to become stressed and frustrated to see children do not want to learn and their thinking ability decreases - they find it difficult to understand the material provided by teachers through learner worksheet (LKPD)" (R2, R12, and R23).

Theme 5: Parental preference for learning for the rest of the 2020/2021 school year

Despite their concern over the negative impact of the Covid-19 pandemic on children's education, most parents $(78.21 \%)$ do not want this distance learning extended and expect the government to reopen schools for the rest of the 2020/2021 school year.

"It is undeniable that distance learning is very burdensome; psychosocial disorders are increasing, especially for children. Children's learning motivation and cognitive abilities tend to decrease. We worry that violence against children at home can increase, not infrequently parents get angry and 
even hit because children are lazy to learn and can not complete the school's tasks. Therefore, we expect this distance learning to end soon. For the rest of the 2020/2021 academic year, so that the government can reopen educational institutions so that the learning process can take place, as usual, namely faceto-face learning in the classroom" (R1, R6, R18, and R24).

Furthermore, they hope that if distance learning is still going on for some time to come, there needs to be attention and support from the school to (1) reduce the cost of education (especially private schools); (2) provide books and teaching materials that students or parents/guardians can take home; and (3) so that teachers are more creative than just distributing LKPD to students, but still maintain contact and communication with students and parents, so that children's learning motivation is maintained.

\section{Discussion}

The above study's findings show that almost all parents are worried about the negative impact of the Covid-19 pandemic on their children's education. It concerns student academic achievement, knowledge acquisition, and several skills (competencies) that are significantly difficult to achieve. "The current challenge is how to achieve distance learning competencies and objectives that are not significantly different from face-toface learning, even better" (Maman F. Febrianti, 2020). This crisis is likely to have significant long-term effects on education, including curriculum and learning. Therefore, this crisis should be an opportunity to rethink the curriculum, teachinglearning process-assessment, and competency development of learners to strengthen their learning skills and maintain their motivation (UNESCO, 2020a).

Inadequate involvement of parents and families to support children's distance learning activities at home is predominantly due to parents' limited time and ability to accompany children in learning. Two factors are economic and social is not uncommon to be a severe obstacle and challenge of the implementation of education. Parents are busy working in various professions and types of work to earn income to cover the cost of meeting the family's needs, so they do not have enough time to accompany the children in learning. On the other hand, parental education also impacts the frequency of children's involvement in academic activities. Children in highly educated families are more often involved in structured academic activities such as worksheets, online school resources, and other educational resources during pandemics (Greenlee \& Reid, 2020).

The findings are in line with previous studies that "a lack of parental awareness and interest in students' school activities are the main causes of their poor academic achievement in secondary school" (Aman et al., 2019). "Parental involvement and investment have a significant effect on students' self-concept and academic achievement in elementary school" (Ho \& Kwong, 2013). Parental involvement in a child's education is consistently positively related to a child's academic performance (Topor et al., 2010).

It switches from actual perception to parental action in favor of learning from home. There is not much that parents do to support their child's activities at home. Except that parents are ultimately obliged to provide internet needs, check the learner's worksheet and help children clarify the subject matter obtained from the school. This situation is exacerbated by the lack of communication between teachers and parents 
and learners who decrease learning motivation. Although this situation is a time of crisis, in the long term, it is not very good for the development of education and the achievement of children's academic achievement. Some research results have provided evidence that parents' and families' involvement in children's learning positively impacts children's achievements (Averill et al., 2016).

Discussing the challenges faced by parents in terms of learning, the research findings were dominated by three factors, namely increased family spending (economic aspects); parental stress due to the increasing pressure of managing restrictions (quarantine) and work (psychological disorders), as well as the relationship and communication (social aspect) of parents with children, as well as between parents and teachers.

Several previous research results show the same indications. The results of Azzahra (2020) research show that disruption to the traditional education system today has harmed students who come from low-income families and who are in rural areas. Even under normal conditions, students have faced barriers to access to education, and now they face additional barriers that arise due to inequality to access technology infrastructure. SMRC research results also support the rising costs borne by parents in relation to learning from home: "Among respondents with family members who do distance learning, 67 percent say it is very or quite expensive" (Ghaliya Ghina, 2020; SMRC, 2020).

The increase in parental psychological disorders occurs due to limited ability to manage the restrictions (quarantine) imposed (see Spinelli et al., 2020). Parents have difficulty balancing time between daily work and mentoring children's learning activities at home and complaining about the complexity of carrying out the role of teacher at home. Some parents claim that there are situations where children are more submissive and respectful to teachers at school than parents at home.

According to the author, related problems are more caused by parents' readiness to become teachers at home. Parents are required to facilitate the online learning needs of children at home, which is the provision of providing gadgets/notebooks or sharing gadgets with children; additional expenses to purchase the data plan. Parents must manage and divide their time between doing daily tasks and accompanying children in learning at home, and ultimately parents acting as teachers for their children (Wardhani \& Krisnani, 2020; Yoenanto, 2020).

A surprising finding in the study was that $48.4 \%$ of parents admitted that their children's learning motivations had decreased. Due to the large number of tasks that must be done in a short time, less pleasant learning methods, and limited interaction with friends. An inability to learn effectively in an online format and a disruptive home environment or lack of access to appropriate study spaces.

This finding is in line with a Save the Children report in CNN Indonesia (2020) that "A total of 42 percent of parents admitted that children's learning motivation decreases overtime during the pandemic." Virtual classes are often confusing and contain information that is too much to track. Deadlines are uncertain, assignments are misleading, and exams are challenging for students to learn (Nell et al., 2020). The condition of the learning environment and family is not conducive, also contributes to the decrease in children's learning motivation (Cahyani et al., 2020; Daugherty, 2020). 
Coexistence with Covid-19 is the reality of our new life today. We cannot predict when these crises are going to be in the dork. This plague at all times threatens our health and safety; everything is carried out with health protocols, with restrictions, of course. However, be aware that the integration of technology into the learning process is inevitable. Classes can no longer be limited to the walls where learning takes place conventionally. In this era, children already have a learning preference; they are born where technology has proliferated. Educational institutions are in the era of rapid and massive technological development (industrial revolution 4.0). It agreed not to agree that educational institutions should adopt and redesign management systems "that refer to ICT-based learning, the internet of things, big data and computers" (Lase, 2019).

Fisk (2017) states that there are nine trends related to education 4.0, among which are "learning at different times and places, and e-learning facilitating opportunities for distance and independent learning." It shows that the covid-19 outbreak is a trigger tool to quickly adapt to technological developments by integrating technology into the learning process. This thinking is also in line with Dunwill (2016) that there will be many future changes. He predicts how class flexibility will look in the next 5-7 years, i.e. (a) significant changes in classroom layout, (b) virtual and augmented reality will change the educational landscape, (c) Flexible assignments that accommodate many learning preferences, and (d) MOOC and other online learning options will have an impact on secondary education.

The increasing cost that parents have to bear in supporting the sustainability of children's education, could be easily answered by the government through the provision of internet packages (this policy is ongoing). But in the medium and long term the availability of technology infrastructure reached by all components of society is an urgent job for the government. Local governments must take the initiative to work with communication technology infrastructure development companies without having to wait for the availability of budgets from the central government.

The lack of teacher skills in integrating technology in the learning process is challenging and requires serious attention from the government. The plan of Program Organisasi Penggerak (POP) initiated by the Ministry of Education and Culture of the Republic of Indonesia is new hope for improving education quality. POP as a dynamic organization project is a massive community empowerment program through government support for improving the quality of teachers and principals based on training models that have been proven effective in improving the quality of the learning process and student learning outcomes (Kemendikbud, 2020). Considering that education issues are also related to parents' involvement in children's education, this program needs to give place to campaign activities to build parents' awareness to improve their children's education process accuracy.

Furthermore, the main thing is parents' paradigm shift to prepare themselves to be teachers for their children at home. Therefore, the following simple guidelines may help parents support children's learning activities at home.

- Managing children's learning time, learning, and completing analytical tasks (such as math) is best done in the morning (Sjosten-bell, 2005).

- Children's moods and feelings affect their learning productivity. Therefore, parents need to check the child's mood through various questions. It can be done every day, even throughout the day. 
- Before parents intervene, encourage children to solve their problems at the highest level of ability and recognize or praise it.

- Engage children in other activities such as discussion, writing, drawing, dancing, listening to excellent music to enhance their creativity, empathy, and language skills.

- Parents need to make time for children to play or exercise.

- Parents do not need to limit the place of learning of children at home; as far as possible, they can study anywhere at home.

\section{Conclusion}

Based on the above research findings, there are at least three main issues related to parents' interest in distance learning, especially in the context of research and in general, in Indonesia's rural areas. Namely, concerning parents' conservative paradigm about education is educational institutions' responsibility; a decrease in children's learning motivation in distance learning, and technology infrastructure distributed unevenly throughout Indonesia.

The misrepresentation of the majority of parents in understanding education is that educational institutions' responsibility has led to their involvement in children's education, and the readiness to be a teacher for children at home is at its lowest level. Meanwhile, the study results have provided evidence that parents' involvement in the child's educational process contributes positively to their academic achievement.

The decrease in children's learning motivation during this crisis is not a single-born issue but contributes from the environment both externally and internally the child itself. Parents' leading role is needed, and even better when other family members support children's study from home activities. Building continuous communication between parents and teachers, parents and children, teachers with students, and students with their groups will significantly help the child's intrinsic motivation to grow and be awake. Even the effects of stress experienced by parents and students can be handled through intense communication between them.

Concerning the availability of telecommunication infrastructure to support the implementation of ICT-based education, it is not a small, cheap, and fast job. It requires goodwill from all parties, especially a government that has great authority and budget. In addition to health, local governments must dare to give priority to handling this aspect. Similarly, education institutions (schools), school funds, or operational costs derived from central government finances will be better if part of it is intended to increase students' accessibility to technology-based education services.

Furthermore, every year villages in Indonesia receive funding from the central government from hundreds of millions to billions (IDR) to build Indonesia from the village's outskirts (Cabinet Secretariat of RI, 2014). Through cooperation between villages, these funds can accelerate the equitable distribution of telecommunication network accessibility in remote areas. 


\section{Acknowledgment}

This research will undoubtedly be challenging to resolve without the support of various parties. Therefore, on this occasion, the author conveyed his deepest gratitude to the Gunungsitoli City Education Office, especially to the father of Angalita Zebua. Also, to the principals and homeroom teachers. They have supported this research in the form of providing and collecting data.

\section{References}

Adnan, M., \& Anwar, K. (2020). Online learning amid the COVID-19 pandemic: Students' perspectives. Journal of Pedagogical Sociology and Psychology, 2(1), 45-51. https://doi.org/10.33902/JPSP.\%202020261309

Aman, J., Akram, M. B., Mas'udah, S., Saud, M., \& Manj, Y. N. (2019). Parental involvement for better education: The relationship between parental awareness, emotional support, and children's academic achievement at secondary level. Masyarakat, Kebudayaan Dan Politik, 32(4), 334. https://doi.org/10.20473/mkp.V32I42019.334-345

Arifin, H. N. (2020). Respon Siswa Terhadap Pembelajaran dalam Jaringan Masa Pandemi COVID-19 di Madrasah Aliyah Al-Amin Tabanan. WIDYA BALINA: Jurnal Ilmu Pendidikan Dan Ekonomi, 5(9), 1-12. https://journal.staidenpasar.ac.id/index.php/wb/article/view/47

Averill, R., Metson, A., \& Bailey, S. (2016). Enhancing parental involvement in student learning. Curriculum Matters, 12, 109-131. https://doi.org/10.18296/cm.0016

Azzahra, N. F. (2020). Mengkaji Hambatan Pembelajaran Jarak Jauh di Indonesia di Masa Pandemi Covid-19. Center for Indonesians Policy Studies, 19(2), 1-9. https://www.cips-indonesia.org/post/mengkaji-hambatan-pembelajaran-jarak-jauhdiindonesia-di-masa-covid-19

Bernard, H. R., \& H. Russell, B. (2006). Reserach methods in Anthropology - Qualitative and Quantitative Approaches. In AltaMira Press. AltaMira Press. https://doi.org/10.1525/aa.2000.102.1.183

Cahyani, A., Listiana, I. D., \& Larasati, S. P. D. (2020). Motivasi Belajar Siswa SMA pada Pembelajaran Daring di Masa Pandemi Covid-19. IQ (Ilmu Al-Qur'an): Jurnal Pendidikan Islam, 3(01), 123-140. https://doi.org/10.37542/iq.v3i01.57

CNN Indonesia. (2020). 7 Dampak Pandemi yang Berisiko Dihadapi Anak-anak. CNN Indonesia. https://www.cnnindonesia.com/gaya-hidup/20200722142651-284527653/7-dampak-pandemi-yang-berisiko-dihadapi-anak-anak

Daugherty, O. (2020). Students Face Obstacles, Lack of Motivation in Transition to Remote Learning Amid Pandemic. In NASFAA. NASFAA. https://www.nasfaa.org/newsitem/22637/Students_Face_Obstacles_Lack_of_Motivation_in_Transition_to_Remote_ Learning_Amid_Pandemic_Report_Finds

Dewi, W. A. F. (2020). Dampak COVID-19 terhadap Implementasi Pembelajaran Daring di Sekolah Dasar. EDUKATIF : JURNAL ILMU PENDIDIKAN, 2(1), 55-61. https://doi.org/10.31004/edukatif.v2i1.89

Dunwill, E. (2016). 4 changes that will shape the classroom of the future: Making education fully technological. https://elearningindustry.com/4-changes-will-shape-classroom-ofthe-future-making-education-fully-technological

Faqir, A. Al. (2020). Kemendikbud Catat 646.200 Sekolah Tutup Akibat Virus Corona. 
https://www.merdeka.com/uang/kemendikbud-catat-646200-sekolah-tutup-akibatvirus-corona.html

Febrianti, R. (2020). Implementasi Kurikulum dan Pembelajaran di Masa Pandemi Covid19. Universitas Negeri Malang. https://um.ac.id/berita/implementasi-kurikulum-danpembelajaran-di-masa-pandemi-covid-19/

Fisk, P. (2017). Education 4.0 ... the future of learning will be dramatically different, in school and throughout life. http://www.thegeniusworks.com/2017/01/future-educationyoung-everyone-taught-together/

Ghaliya Ghina. (2020). Majority of Indonesians find distance learning costly: Study. The Jakarta Post. https://www.thejakartapost.com/news/2020/08/19/majority-ofindonesians-find-distance-learning-costly-study.html

Greenlee, E., \& Reid, A. (2020). Parents supporting learning at home during the COVID-19 pandemic. Statistic Canada. https://www150.statcan.gc.ca/n1/pub/45-280001/2020001/article/00040-eng.htm

Heriyanto, H. (2018). Thematic Analysis sebagai Metode Menganalisa Data untuk Penelitian Kualitatif. Anuva, 2(3), 317. https://doi.org/10.14710/anuva.2.3.317-324

Herliandry, L. D., Nurhasanah, Suban, M. E., \& Kuswanto, H. (2020). Pembelajaran Pada Masa Pandemi Covid-19. 22(1), 65-70. https://doi.org/10.21009/jtp.v22i1.15286

Ho, E. S.-C., \& Kwong, W.-M. (2013). Effects of Parental Involvement and Investment on Student Learning. In Parental Involvement on Children's Education (pp. 131-148). https://doi.org/10.1007/978-981-4021-99-9_5

Jandrić, P. (2020). Postdigital Research in the Time of Covid-19. Postdigital Science and Education, 2(2), 233-238. https://doi.org/10.1007/s42438-020-00113-8

Krishnapatria, K. (2020). From 'Lockdown' to Letdown: Students' Perception of E-learning amid the COVID-19 Outbreak. ELT in Focus, 3(1), 1-8. https://doi.org/10.35706/eltinfe.v3i1.3694

Lase, D. (2019). Education and Industrial Revolution 4.0. Handayani Journal PGSD FIP Unimed, 10(1), 48-62. https://doi.org/10.24114/jh.v10i1.14138

Marshall, C., \& Rossman, G. B. (2015). Designing Qualitative Research (6th ed.). SAGE Publications, Inc.

Megawanti, P., Megawati, E., \& Nurkhafifah, S. (2020). Persepsi Peserta Didik Terhadap PJJ Pada Masa Pandemi Covid 19. Faktor Jurnal Ilmiah Kependidikan, 7(2), 75-82.

Moleong, L. J. (2012). Metodologi Penelitian Kualitatif. PT Remaja Rosdakarya.

Nell, A., Hood, M., \& Graff, H. (2020). Student Motivation During COVID 19 Pandemic. In A\&S Academic Advising Center. A\&S Academic Advising Center. https://www.colorado.edu/artssciences-advising/2020/04/21/student-motivation-duringcovid-19-pandemic

Pei, L., \& Wu, H. (2019). Does online learning work better than offline learning in undergraduate medical education? A systematic review and meta-analysis. Medical Education Online, 24(1), 1666538. https://doi.org/10.1080/10872981.2019.1666538

Puspita, R. (2020, August 4). Kemendikbud: 68 Juta Siswa Terdampak Pandemi Covid-19. REPUBLIKA.Co.Id. https://republika.co.id/berita/qejb7r428/kemendikbud-68-jutasiswa-terdampak-pandemi-covid19

Putri, R. S., Purwanto, A., Pramono, R., Asbari, M., Wijayanti, L. M., \& Hyun, C. C. (2020). Impact of the COVID-19 Pandemic on Online Home Learning: An Explorative Study of Primary Schools in Indonesia. International Journal of Advanced Science and 
Technology, 29(05), 4809-4818.

http://sersc.org/journals/index.php/IJAST/article/view/13867

Sjosten-bell, W. (2005). Influence of Time-of-Day on Student Performance on Mathematical Algorithms. In Dominican University of California (Issue December). Dominican University of California.

Skulmowski, A., \& Rey, G. D. (2020). COVID-19 as an accelerator for digitalization at a German university: Establishing hybrid campuses in times of crisis. Human Behavior and Emerging Technologies, 2(3), 212-216. https://doi.org/10.1002/hbe2.201

SMRC. (2020). Mayoritas Warga Menganggap Berat Biaya Pendidikan Online. SaifulMuljani Research \& Consulting. https://saifulmujani.com/mayoritas-wargamenganggap-berat-biaya-pendidikan-online/

Spinelli, M., Lionetti, F., Pastore, M., \& Fasolo, M. (2020). Parents' Stress and Children's Psychological Problems in Families Facing the COVID-19 Outbreak in Italy. Frontiers in Psychology, 11. https://doi.org/10.3389/fpsyg.2020.01713

Topor, D. R., Keane, S. P., Shelton, T. L., \& Calkins, S. D. (2010). Parent Involvement and Student Academic Performance: A Multiple Mediational Analysis. Journal of Prevention \& Intervention in the Community, 38(3), 183-197. https://doi.org/10.1080/10852352.2010.486297

UNESCO. (2020a). COVID-19 Crisis and Curriculum: Sustaining Quality Outcomes in the Context of Remote Learning. UNESDOC Digital Library, 4.2, 1-6. https://unesdoc.unesco.org/ark:/48223/pf0000373273

UNESCO. (2020b). School closures caused by Coronavirus (Covid-19). In Unesco. https://en.unesco.org/covid19/educationresponse

Viva. (2020, April 4). Terdampak Corona, 34,5 Persen Pelajar Indonesia Tak Terakses Pendidikan Online. Suara Merdeka.

https://www.suaramerdeka.com/news/nasional/224640-terdampak-corona-345-persenpelajar-indonesia-tak-terakses-pendidikan-online

Wardhani, T. Z. Y., \& Krisnani, H. (2020). OPTIMALISASI PERAN PENGAWASAN ORANG TUA DALAM PELAKSANAAN SEKOLAH ONLINE DI MASA PANDEMI COVID-19. Prosiding Penelitian Dan Pengabdian Kepada Masyarakat, 7(1), 48. https://doi.org/10.24198/jppm.v7i1.28256

Yoenanto, N. H. (2020). Kesiapan Orangtua Menjadi Guru di Rumah. https://psikologi.unair.ac.id/wp-content/uploads/2020/05/13-Kesiapan-OrangtuaMenjadi-'Guru'-di-Rumah.pdf

Zaharah, Z., \& Kirilova, G. I. (2020). Impact of Corona Virus Outbreak Towards Teaching and Learning Activities in Indonesia. SALAM: Jurnal Sosial Dan Budaya Syar-I, 7(3). https://doi.org/10.15408/sjsbs.v7i3.15104 